\title{
THE ADOPTION OF THE ARCGIS SYSTEM TO SUPPORT THE ANALYSES OF THE INFLUENCE OF THE MINING TREMORS ON THE BUILDING OBJECTS
}

\author{
Violetta SOKO ŁA-SZEWIOŁA, Monika ŻOGA ŁA \\ Silesian University of Technology
}

\begin{abstract}
:
Nowadays the mining companies use the Spatial Information System in order to facilitate data management, gathered during the mining activity. For these purposes various kinds of applications and software information are used. They allow for faster and easier data processing. In the paper there are presented the possibilities of using the ArcGIS system to support the tasks performed in the mining industry in the scope of the analysis of the influence of the mining tremors, induced by the longwall exploitation on the facilities construction sited on the surface area. These possibilities are presented by the example of the database developed for the coal mine KWK "Rydułtowy-Anna." The developed database was created using ArcGIS software for Desktop 10. 1. It contains the values of parameters, specified for its implementation relevant to the analyses of the influence of the mining tremors on the surface structures.
\end{abstract}

Key words: ArcGIS, geoinformatics, mining, spatial information systems, mining tremors

\section{INTRODUCTION}

The development of the spatial information systems (SIS) also influences the mining industry. The underground mines as well as open pit make use of such a kind of systems by using geoinformatics tools. In the applications such as: reclamation planning and development, the evaluation of mining conditions of the conducting exploitation, including threats monitoring and the identification of areas of deposit exploration, corporations have a chance to support themselves by Geographical Information Systems (GIS).

One of the first solution that supported mining geodesy and the protection of mining areas was an adoption of the markup languages [4]. Until the year 2004, one of the most important application of this was a HTML language usage to visualize data that were obtained from the measurement of the deformation of the mining area, "Rudna" [4]. Even then, these solutions were based on the measurement data tables. Two of the most important markup languages for maps' description, which evolved as a result of the development of this direction, are:

- VML - proposed and highly supported by the Microsoft company, focused only on the processing of vector graphics,

- GML - proposed by OGC, accepted and supported by ISO, its the most important advantage is the possibility of using other ISO standards. At the same time, it enables overlapping a map of this language stored in different coordinate systems.

The breakthrough for the use of solutions based on the GIS systems was the Regulation on the geological-survey documentation issued in 2011 [6]. It allowed for a creation of a full range of measurement, computing and cartographic documentation in a numerical form, which contributed to the dynamic development of information systems related to the mining activities. Thereby, it was possible to observe the intensive growth of various types of applications and informative solutions used in the mining industry. Currently valid regulation in this matter was issued in 2015 [7], that still allows the creation of documents in a numerical form. It is significant that it clearly pointed out the need to create it maintaining the geodetic and cartographic law and the requirements stated in Polish standards - Mining Maps. However in Poland there is not any uniform or standardized set of applications. Each mining company develops the individual ways to store and process digital data.

In the mines of the Jastrzebska Coal Company S.A. a Standardized System for Managing Documents and Mining - Survey Documentation has been implemented. The database itself is based on MS SQL Server tools. The system of Katowice Coal Holding S.A. is based on the Bantley Microstation software and so is LW "Bogdanka." The safe solution in the scope of systems meet a GIS function is the system called The Numerical Deposit Model, which was based on the AutoCAD Civil program with the use of the Oracle Spatial program [8].

It seems that the use of ArcGIS software to the needs of the mining activity is currently negligible in Poland and the dominant role of the typical GIS systems is performed by MicroStation. ArcGIS is a collection of GIS software packages that is used to work on the spatial data, used depending on the needs of the user. It is used in many industries such as: business, education, infrastructure and telecommunications, spatial planning and the city planning and the environment, including geology. It is possible to be used to conduct the analyzes of the impact of induced seismicity on the building objects located on the surface, in particular to rec- 
ord the mining damage [10]. This issue is particularly important due to the fact that the extraction of coal from the seams endangered by the rock bursts intensively increases. It is estimated that the share of coal output from the endangered rock burst seams in the total output in the region of Upper Silesian Coal Basin (GZW) actually is at about 50\%. The number of high-energy tremors induced by the mining exploitation has also increased. In 2013 at the GZW they were recorded as 1427 and in the year 2014 even 1765 [5]. In such conditions it is important to perform a correct assessment of the influence of the mining tremors on the infrastructure on the surface area. The element of the building objects' risk assessment as a result of induced seismicity, is an evaluation and registration of damage that occurred in the buildings after strong tremors, which can support works connected also with mining exploitation planning in the region where induced seismicity occurs. In the paper are presented the possibilities of the use of the above-mentioned software to support the evaluation of the mining tremors impact on the building objects by the example of the database developed for the coal mine KWK "Rydułtowy-Anna."

\section{THE CHARACTERISTIC OF THE SURVEY DATA}

The KWK "Rydułtowy-Anna" mining area is divided into two district: OG "Rydułtowy I" and OG "Pszów II" [2].

On the surface of the analyzed area there is cubature development, including primarily residential buildings, facilities and industrial buildings but there are also many public buildings such as: schools, churches, offices, hospitals, sports and cultural facilities, commercial buildings and clinics [1].
In the coal mine KWK "Ryduttowy-Anna," the exploitation is conducted under the following threat conditions: methane, a coal dust explosion, the outbursts of methane and rocks, rock-bursts, water, temperature and the radioactive substances. In years 2011-2013, the exploitation was conducted there in the seams $703,706,707 / 1-2,713 / 1$, and $713 / 1-2[3]$.

The GIS database was compiled for an area, where damage in the building objects occurred as a result of mining tremors of seismic energy of $10^{7} \mathrm{~J}$, induced by the exploitation conducted in the seam 713/1-2. Mining works that were conducted in that seam in years 2011-2013, induced 8 tremors of the above-mentioned energy.

In order to determine the scope of attributes of the objects that entered into the database used: 89 registration sheets of the building objects, 274 inspection reports including data concerning damage to the buildings. data concerning the mining tremors induced by conducting operation of seismic energy of $10^{7} \mathrm{~J}$, a map of the dynamic areas, a mining map of the seams $713 / 1-2$, and $713 / 1-2+712 / 1-2$, materials in the form of an analog including data concerning damage to the buildings as a result of the abovementioned tremors.

The Table 1 performs the number of objects where the inspection in connection with the recorded tremors took place, taking the type of notification into account.

The analysis of the obtained data allowed to claim that as a result of these tremors till 240 building objects were damaged, including 36 public buildings, the remaining are the residential buildings, (Table 2 ).

Table 1

The inspection performed in the objects in connection with recorded tremors depending on the type of notification

\begin{tabular}{ccccc}
\hline & \multicolumn{3}{c}{ The number of objects where the inspection took place } \\
\hline Tremors' date & Coal mine-public buildings & Phone notification & $\begin{array}{c}\text { Coal mine- objects in the region } \\
\text { of the epicenter of the tremor }\end{array}$ & Total inspection \\
30.06 .2013 & 6 & 8 & 5 & 19 \\
07.062013 & 14 & 63 & lack of information & 77 \\
02.06 .2013 & 4 & 22 & lack of information & 26 \\
22.02 .2013 & 8 & 12 & lack of information & 20 \\
12.09 .2011 & 21 & 10 & lack of information & 31 \\
15.07 .2011 & 5 & 7 & 5 & 13 \\
21.04 .2011 & 9 & 69 & 13 & 91 \\
30.03 .2011 & 6 & 42 & 36 & 31 \\
Total & $\mathbf{7 3}$ & $\mathbf{2 3 3}$ & $\mathbf{3 4 2}$ \\
\hline
\end{tabular}

Table 2

The number of objects which were damaged as a result of tremors

The number of objects which were damaged as a result of tremors

\begin{tabular}{lccc}
\hline & \multicolumn{3}{c}{ The number of objects which were damaged as a result of tremors } \\
\hline & Public buildings & Residential buildings & $\begin{array}{c}\text { The total number } \\
\text { of buildings included in the database }\end{array}$ \\
30.06 .2013 & 4 & 9 & 13 \\
07.062013 & 6 & 59 & 65 \\
02.06 .2013 & 3 & 23 & 26 \\
22.02 .2013 & 3 & 12 & 15 \\
12.09 .2011 & 6 & 7 & 13 \\
15.07 .2011 & 3 & 12 & 15 \\
21.04 .2011 & 6 & 42 & 48 \\
30.03 .2011 & 5 & 40 & 45 \\
& & & 240 \\
\hline
\end{tabular}




\section{THE SPECIFIED DATA RELEVANT TO THE NEEDS TO SUP- PORT THE ANALISIS OF THE IMPACT OF MINING TREMORS ON THE BUILDING OBJECTS.}

The analysis of data listed in the chapter 2 allowed for specifying the scope of attributes important for supporting the analysis of the mining tremors impact on the building objects. The attributes are:

- the number of the registration sheets

- the coordinates of the centroid for individual buildings (the type and description),

- address data (a town and an address),

- the distance from the epicenter,

- a technical condition of the object before the tremor,

- the category of static resistance,

- the category of a mining area,

- caused damage (the enlargement of the existing damage, new damage, huge damage),
- the intensity of vibration in $\mathrm{GSI}_{\mathrm{GzWkw}}-2012 \mathrm{v}$ scale (optionally).

In the attributes related to tremors came:

- the coordinates of the epicenter of a tremor,

- the dates of the occurrence of a tremor,

- the hour of the occurrence of a tremor,

- the seismic energy.

\section{THE DEVELOPMENT OF A DATABASE IN THE ARCGIS SYSTEM}

The database was compiled in the ArcGIS system v. 10.1 with accordance with the procedure introduces in the Figure 1. The analysis of existing legislation acts technical standards was conducted, the analysis and preparation of the source materials (chapter 2), as the result the important parameters for the base were specified which is presented in the chapter 3 and then the input files were elaborated in the Microsoft Excel program.

The proces of database software

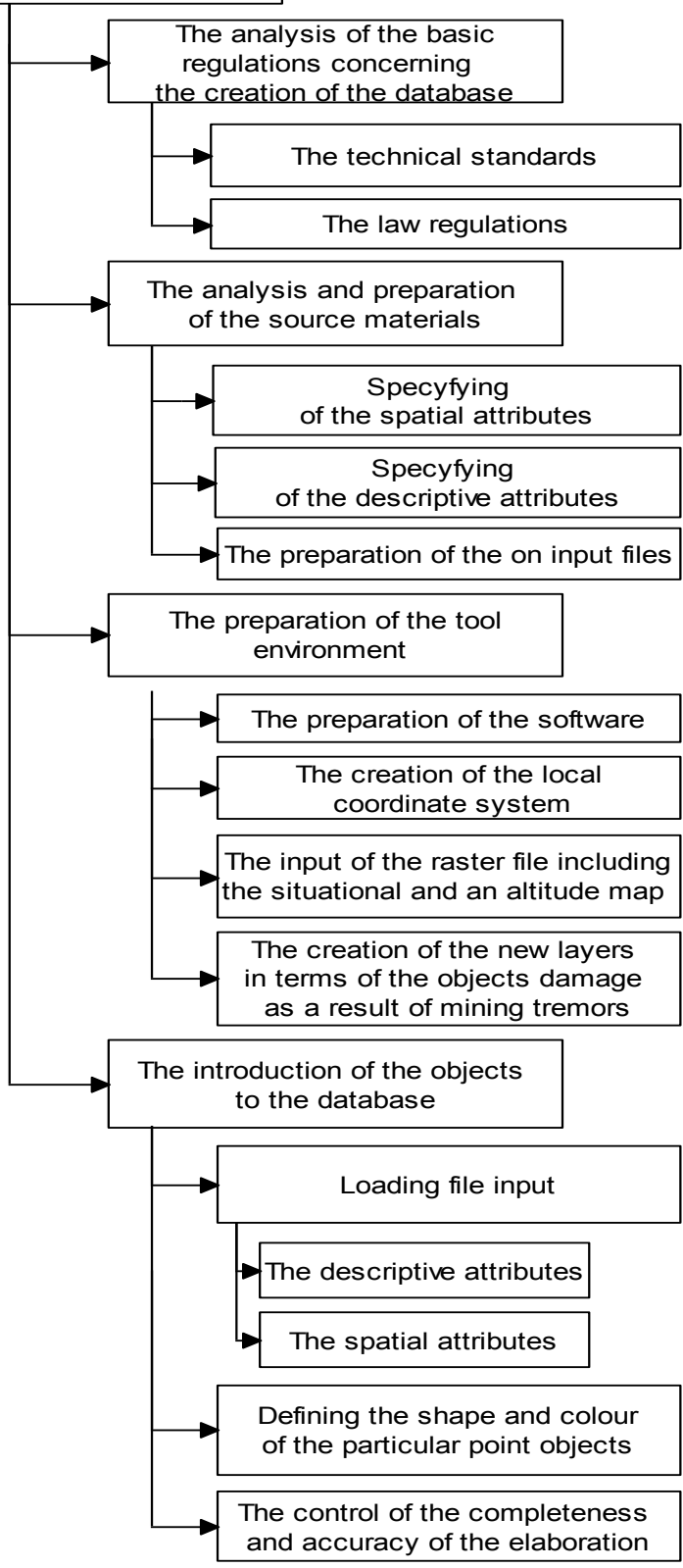


V. SOKOŁA-SZEWIOŁA, M. ŻOGAŁA - The adoption of the ArcGIS system to support the analyses of the influence of the mining...

\begin{tabular}{|c|c|c|c|c|c|c|c|c|c|c|c|c|c|}
\hline \multirow[b]{2}{*}{ Lp. } & \multirow[b]{2}{*}{ Numer arkusza } & \multirow[b]{2}{*}{$\begin{array}{c}\text { Informacje a budynku } \\
\text { (radzaj i apis ) }\end{array}$} & \multicolumn{2}{|c|}{ Ws páłręęne } & \multirow{2}{*}{$\begin{array}{c}\text { Odległaść } \\
\text { ad } \\
\text { epicentrum }\end{array}$} & \multicolumn{2}{|c|}{ Dane adres awe } & \multirow{2}{*}{$\begin{array}{l}\text { Kategaria } \\
\text { terenu } \\
\text { gúrnizego }\end{array}$} & \multirow{2}{*}{$\begin{array}{l}\text { Kategaria } \\
\text { adparnaśa } \\
\text { statyanej }\end{array}$} & \multirow{2}{*}{$\begin{array}{c}\text { Stan } \\
\text { technizany } \\
\text { budynku } \\
\text { pred } \\
\text { wstræem } \\
\end{array}$} & \multicolumn{3}{|c|}{ Paws tałe uszkadzenia } \\
\hline & & & $x$ & $\gamma$ & & Miejs cowaść ć & Adres & & & & $\begin{array}{l}\text { powięls zenie się } \\
\text { is tniejących }\end{array}$ & nawe & duże \\
\hline & 1 & 2 & 3 & 4 & 5 & 6 & 7 & 8 & 9 & 10 & 11 & 12 & 13 \\
\hline 1 & $506 / 09$ & budynek mieszkalny & -38370 & -32390 & 150 & Ryduttawy & 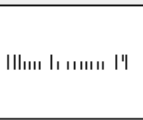 & "I & 2 & dabry & brak & $\begin{array}{c}z a r y s \text { awania tynków } \\
\text { ścian wewnettrnnych, } \\
\text { w fas etach, na } \\
\text { stopkach dżwigaróws } \\
\text { stalowych }\end{array}$ & brak \\
\hline 2 & $412 / 09$ & $\begin{array}{l}\text { budynek mieszkalna- } \\
\text { us tugawy }\end{array}$ & -38940 & -32880 & 500 & Ryduttawy & 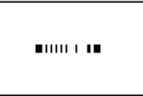 & III & 3 & dabry & brak & $\begin{array}{c}\text { Pęknnięcie tynków na } \\
\text { cakale, zarys awania } \\
\text { tynkówścian } \\
\text { wewnętranych, fas et }\end{array}$ & brak \\
\hline 3 & $17 / 2004$ & budynek mieszkalny & -39560 & -32625 & 960 & Ryduttawy & ', тrmayu & "1 & $\begin{array}{c}\text { brak } \\
\text { infarmacji }\end{array}$ & dabry & brak & $\begin{array}{l}\text { zarys awania i drabne } \\
\text { pęknięcia na tynkaa } \\
\text { zewnętranych, } \\
\text { tynkach weysa., fazet } \\
\text { i na stykach płyt gips- } \\
\text { kartan. } \\
\end{array}$ & brak \\
\hline 4 & $163 / 01$ & $\begin{array}{c}\text { budynek mieszkalnyz } \\
\text { praybudáwką } \\
\text { gos podarąa } \\
\end{array}$ & -38620 & -31860 & 600 & Ryduttawy & 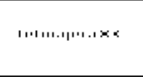 & 1 & 2 & dabry & brak & $\begin{array}{c}\text { peeknięcia tynkáw } \\
\text { ścian wewnętrnytrt i } \\
\text { zewnętrznych, fas et }\end{array}$ & brak \\
\hline 5 & $157 / 09$ & budynek mieszkalny & -38320 & -32200 & 420 & Ryduttawy & 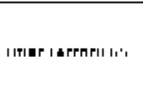 & "1 & 2 & dabry & brak & $\begin{array}{c}\text { zarys awania tynków } \\
\text { fas et, } \\
\text { rozregulawanie } \\
\text { akien }\end{array}$ & brak \\
\hline 6 & $319 / 11$ & $\begin{array}{l}\text { budynek mies zkalny } \\
\text { jednaradzinnyz } \\
\text { przybudáwką } \\
\text { gas padarcą }\end{array}$ & -39260 & -33900 & 1530 & Pszów & 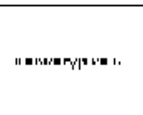 & 0 & 2 & dabry & brak & $\begin{array}{c}\text { zarys owania tynków } \\
\text { ścian, fas et, } \\
\text { pęknięcia tynków na } \\
\text { kaminie ponad } \\
\text { dachem }\end{array}$ & brak \\
\hline 7 & $151 / 01$ & $\begin{array}{c}\text { budynek mieszkalnyz } \\
\text { prybudáwką }\end{array}$ & -38700 & -31940 & 590 & Ryduttawy & 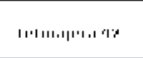 & "1 & 2 & zadawalający & brak & $\begin{array}{c}\text { zarys awania tynków } \\
\text { na pads ufitkach }\end{array}$ & brak \\
\hline
\end{tabular}

Fig. 2 A fragment of an Excel sheet

These files contained specified spatial and descriptive attribute values mentioned in the chapter 3 . Eight files of the damaged objects as a result of the tremors were created and the one including date on the tremors. In the Figure 2 it is visible the part of a file that includes the date on the mentioned above objects. The most important stage of works, from the view point of developing of a database, is a preparation of the tool environment and the introduction of the spatial attribute values and descriptive objects.

The database was elaborated in base of the ArcGIS program, ver. 10.01 of the ESRI firm. The two applications were used to the software which are ArcMap and ArcCatalog. At this stage, apart from the tool environment preparation there were introduced subsidiary data recorded in the raster file presenting the situation on the surface and the coordinate grid of the local SG-ROW scheme was created. To associate the above-mentioned file with the created grid of crosses of the local coordinate grid the application of ArtCatolog was used. The local coordinated grind was created after the installation of the additional plug Fishnet made available free of charge on the Internet.

After the generating of the grid the calibration of the raster picture was made, ending the process of fitting the raster picture into the local coordinate system. These and further steps, concerning the elaboration of the database, were done by the means of ArcMap application.

In the next stage, the data concerning the epicenters of the mining tremors and the building objects representing the content of this database were introduced. The spatial and descriptive attributes values of these objects were introduced. The function of import was used of the prepared input files. After the completion of loading each layer began to determine the shape and colour of the pointed objects, including the tremor epicenter and the centroids of the building objects damaged as a result of the tremors. The pointed objects determine the tremors' epicenters were marked with a red colour (Fig. 3).

The centroids of the building objects, damaged as a result of the individual tremors were marked with colours: in the Figure 4 are presented the damaged objects as a result of a tremor on 21.04.2011.

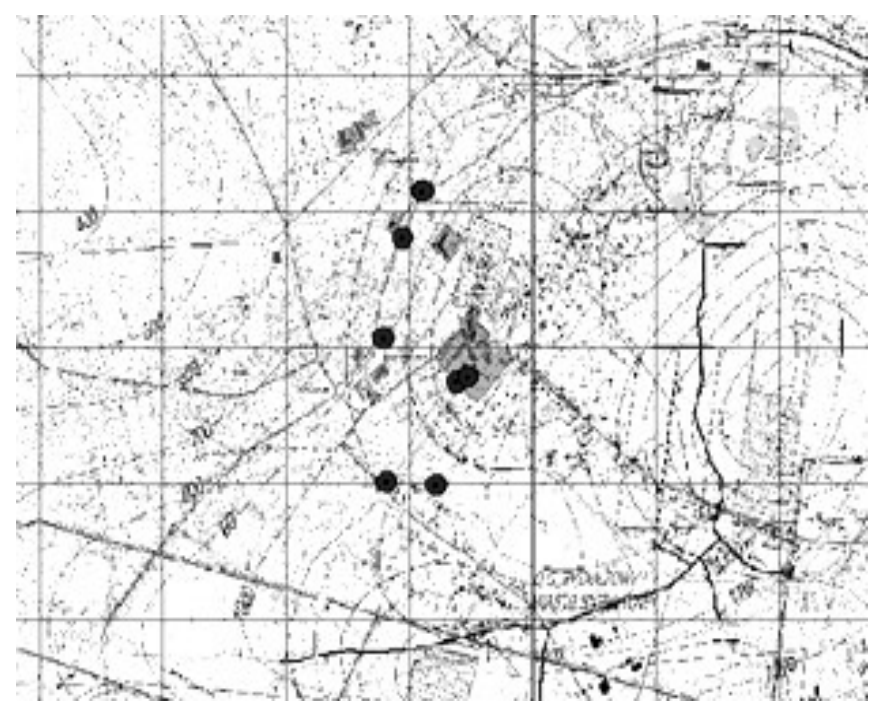

Fig. 3 The part of a map with a symbol of tremors epicentre location

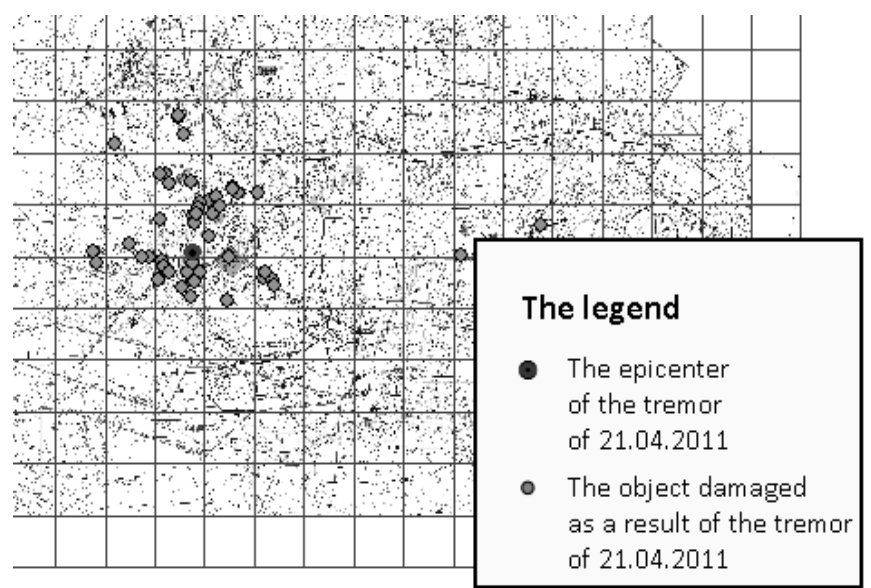

Fig. 4 The damaged objects as a result of the tremor of 21.04.2011 and the epicenter of the tremor 
THE ANALYSIS OF DATABASE USAGE TO SUPPORT THE ASSESSMENT OF THE RESULTS OF THE TREMORS ON THE BUILDING OBJECTS.

The ArcGIS software possess many options that allow to use the function of a spatial analysis. Such analyses allow for performing works both on the spatial and descriptive data. As a result of performing such a task it is possible to obtain different types of values: logical, numerical or quite new data sets [9].

One of the simplest function of the spatial analysis is indication. Thanks to it, if you indicate, for example, any object that is introduced into the database, it is possible to view the set of attributes describing it, concerning for example, information about the coordinates of the objects, its damage and the date of a tremor as a result of which the object was damaged (Fig. 5).

Another feature that enables to perform the spatial analysis is a selective search. It consists in the determining of the logical condition and determination of the objects that meet such a condition. It enables to display, for example, all damaged objects as a result of the chosen tremor and located in a given place. The example of such a search is presented in the Figure 6.

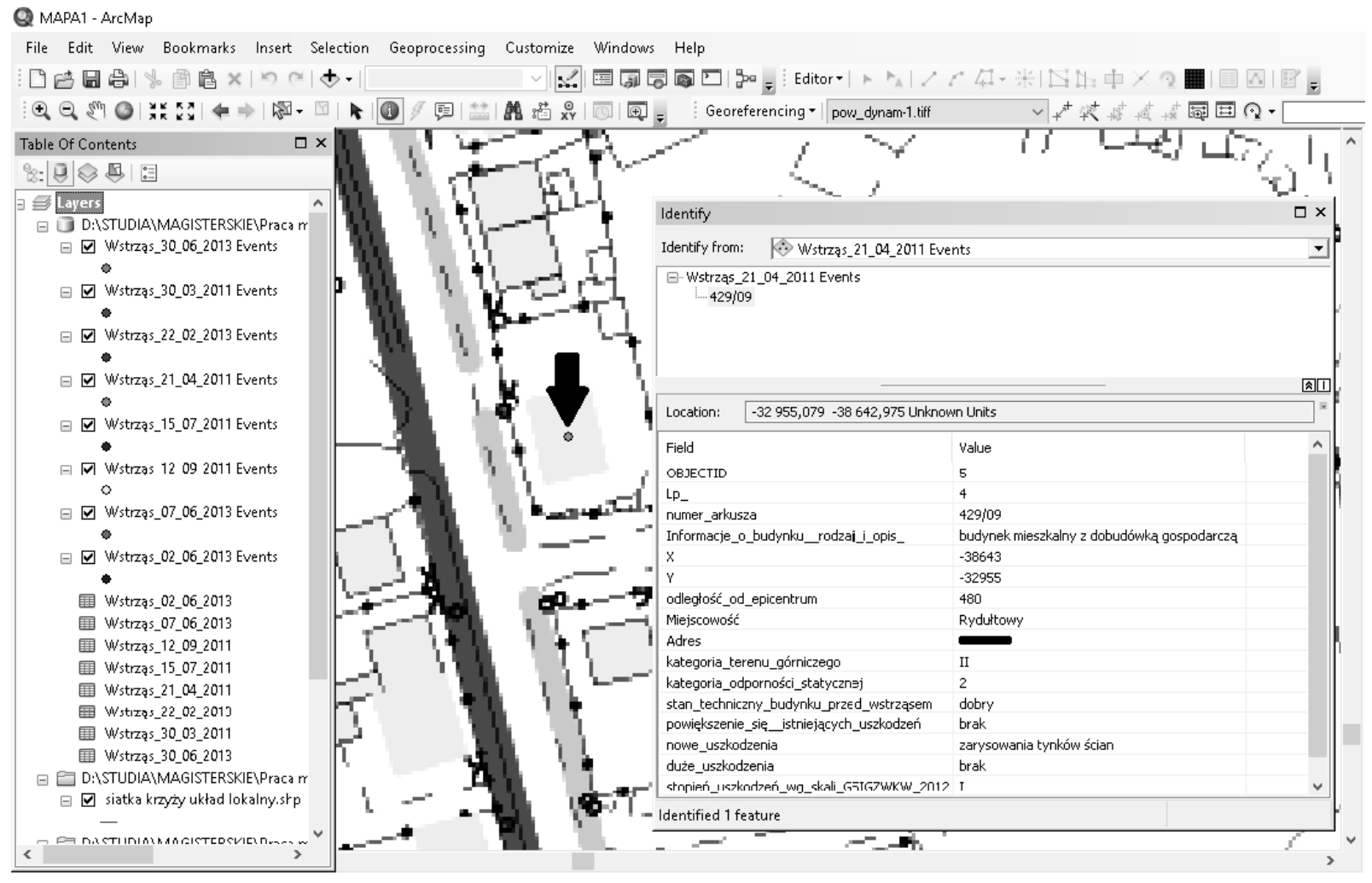

Fig. 5 The example of the use of the indication function

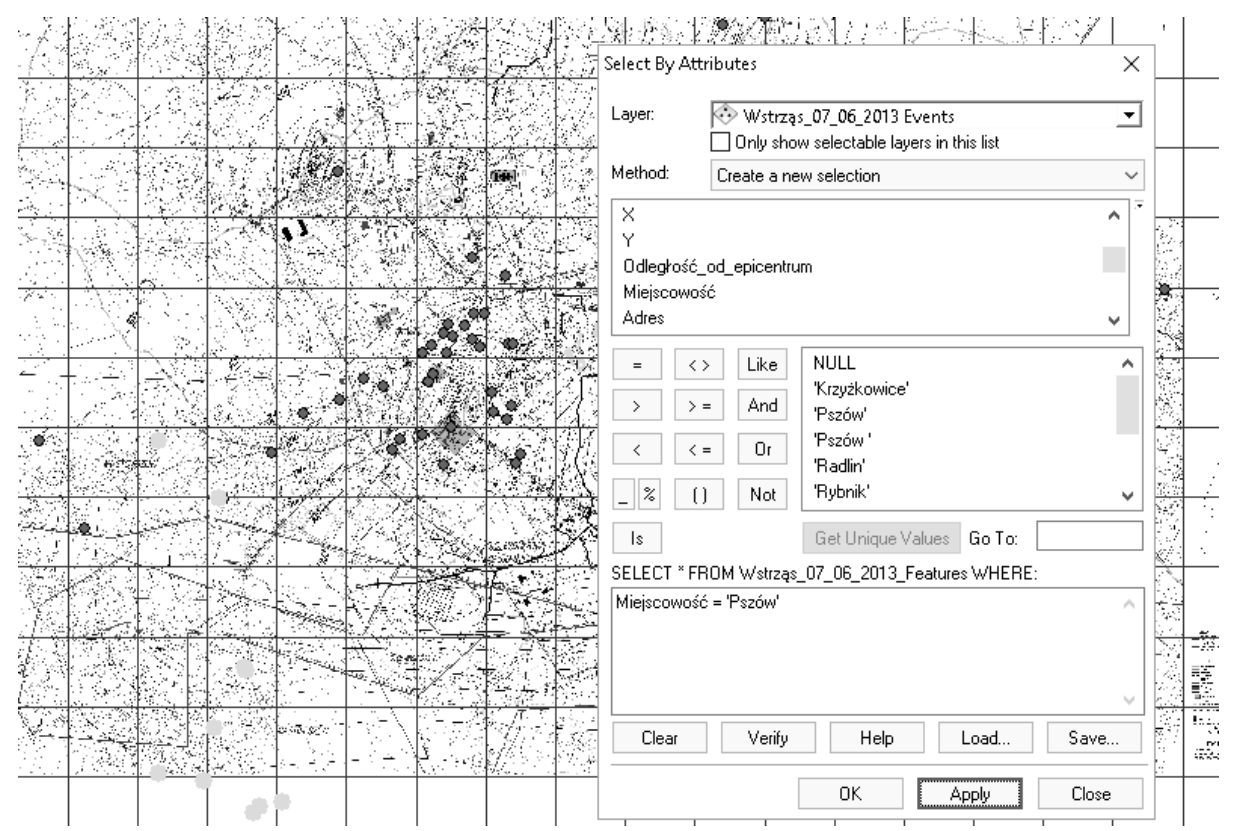

Fig. 6 The example of the use of a selective search 
It is worth mentioning about the possibilities of the neighbouring function. It characterized that it allows to study the surroundings of the chosen object or a place. Setting a focal point, it is determined the coverage area and a parameter, on the basis of which a program is to investigate this feature. For example, the indication of the damaged objects as a result of the tremor on 30.03.2011. located in the distance from the epicentre of more than $420 \mathrm{~m}$ (Fig. 7).
Using the selective function search, it is posssible to display, for example, the simple graph that takes into account a chosen descriptive attribute and the number of objects selected in the first question (Fig. 8).

There is also a possibility of a display of analyses effects by the means of a histogram. The dependence of the number of damaged buildings from a distance of the objects from the tremor epicentre of 07.06 .2013 is presented in the Figure 9.

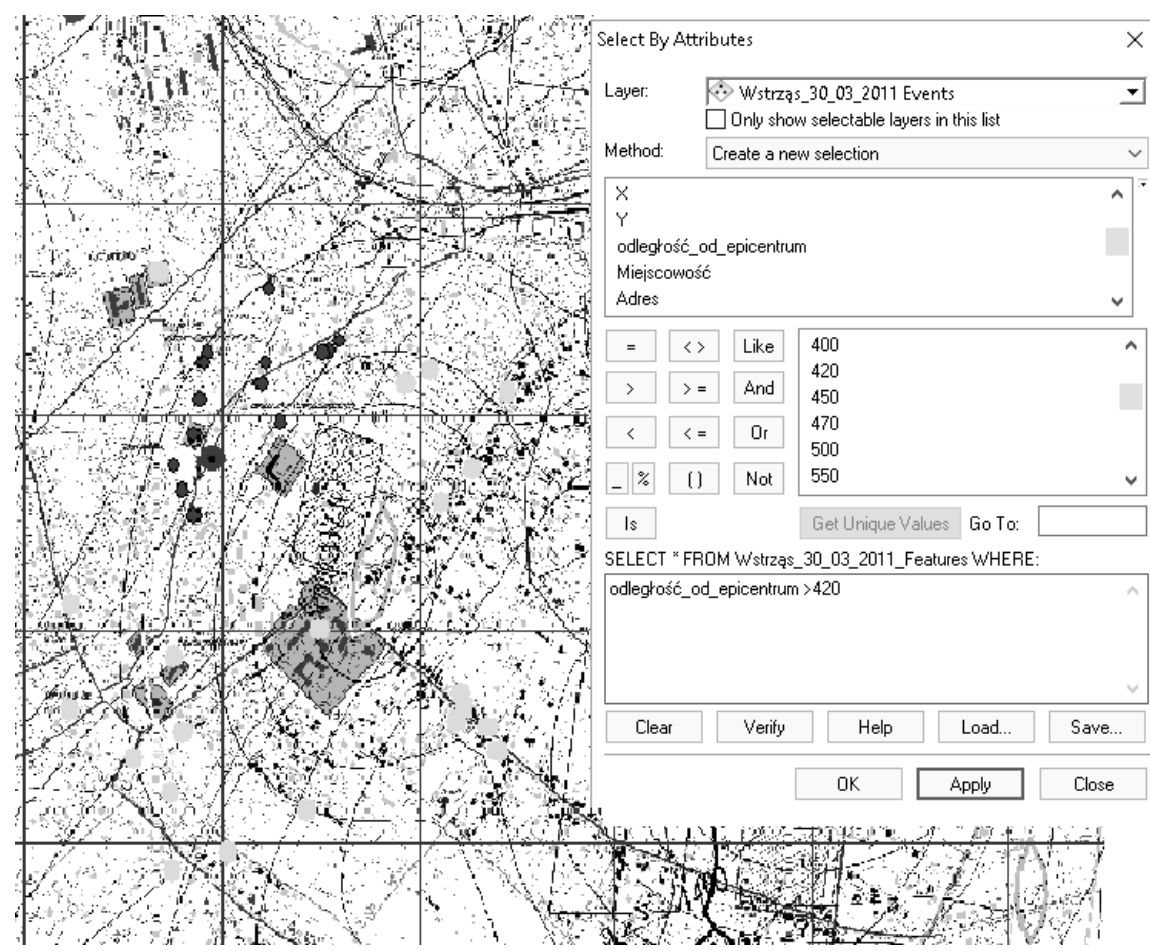

Fig. 7 The example of the use of the neighberhood function

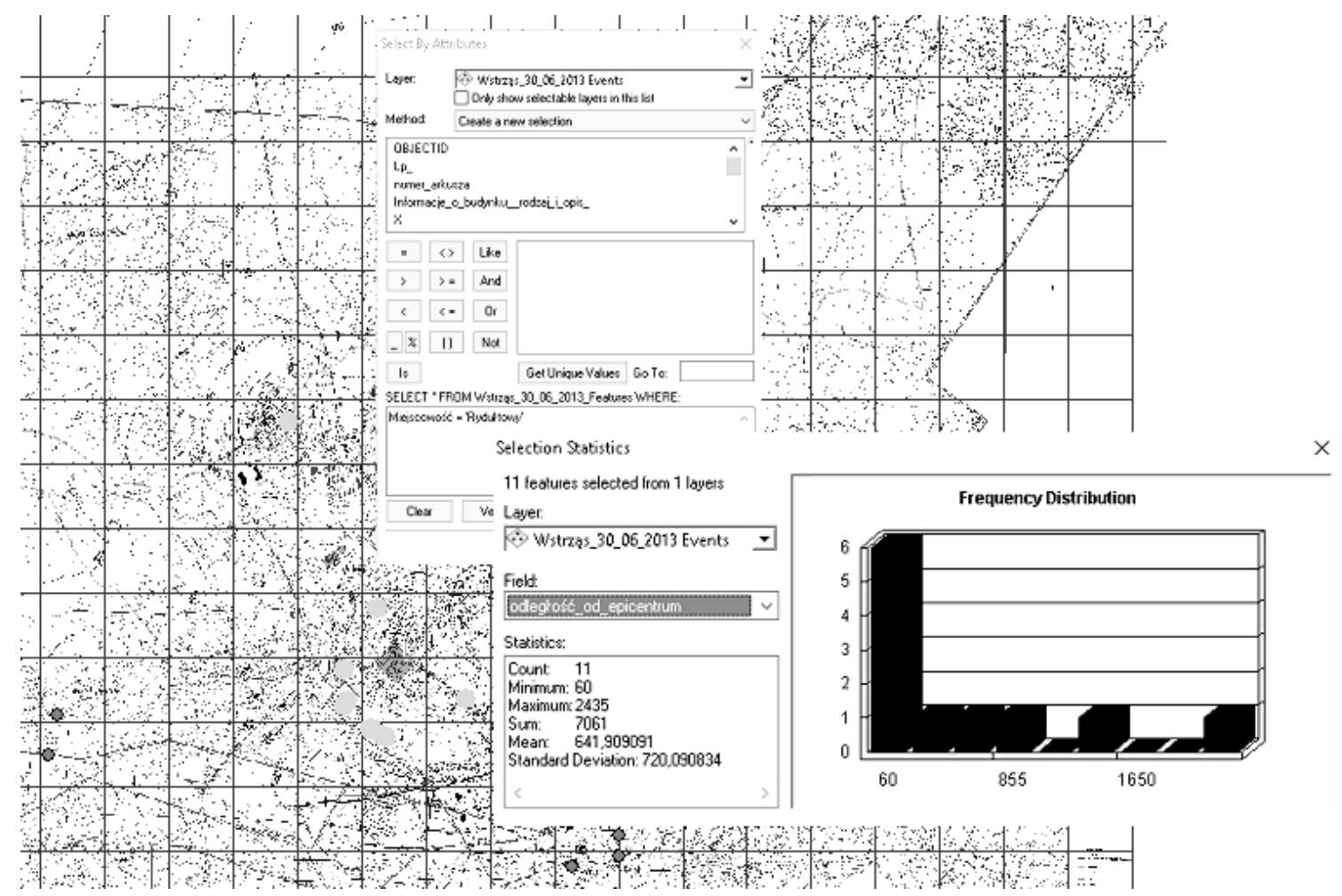

Fig. 8 The juxt aposition of the selective search function with a creation of the simple graph that takes into account the indicated attribute 


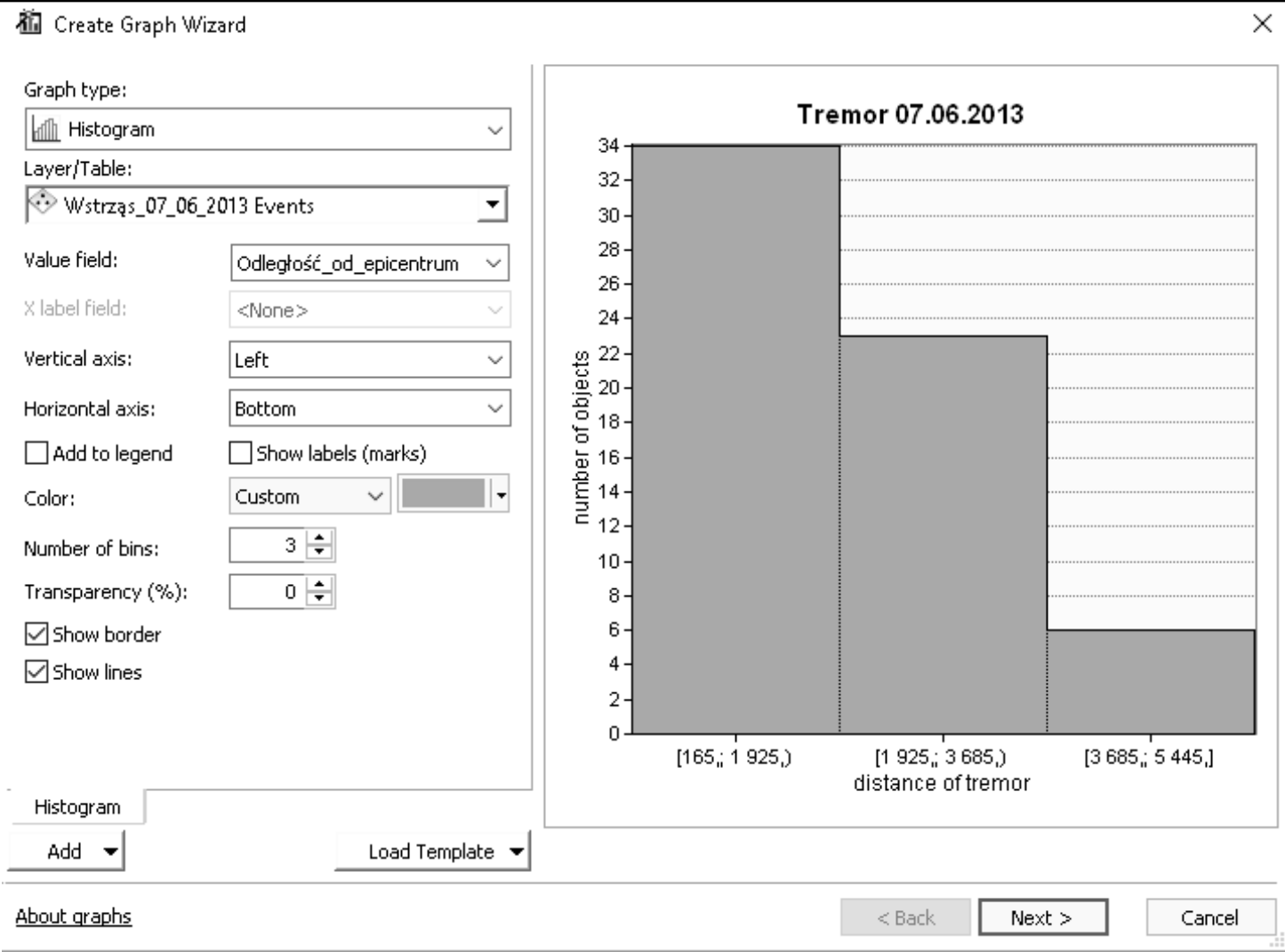

Fig. 9 The histogram of the dependance of number of buildings from the distance of the epicentre

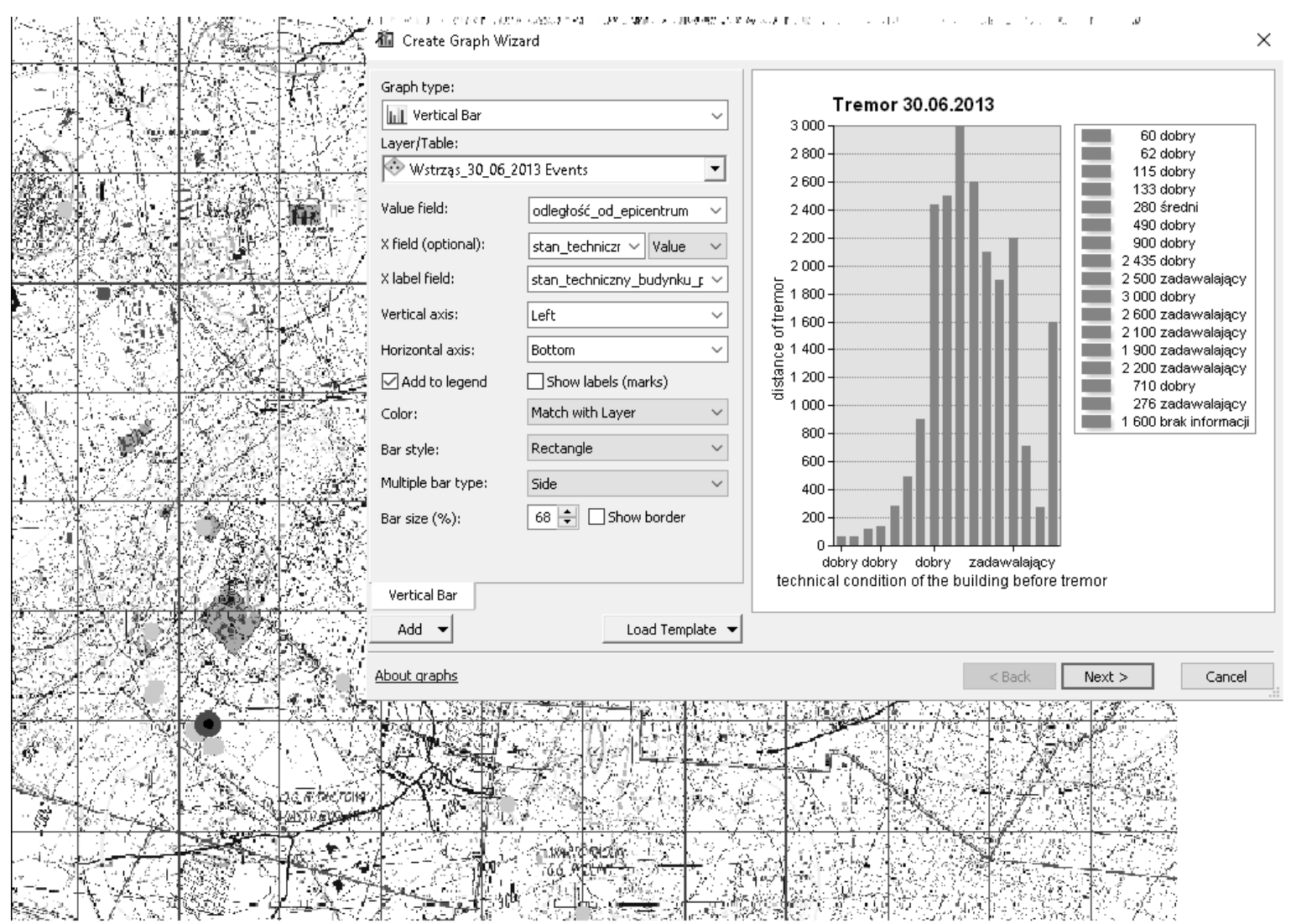

Fig. 10 The classification of the objects depending on the technical condition and the distance from the epicentre of a tremor

In the similar way, it is very possible to make a very quick classification of objects, taking into account a technical condition of the before a tremor (Fig. 10) or a classification of the objects that included damage as a result of a tremor.
Such a database can support a diagnostic evaluation of the buildings by enabling a quick overview of damage to buildings as a result of a tremor (Fig. 11) or allow comparison of damage of the objects after further tremors. 


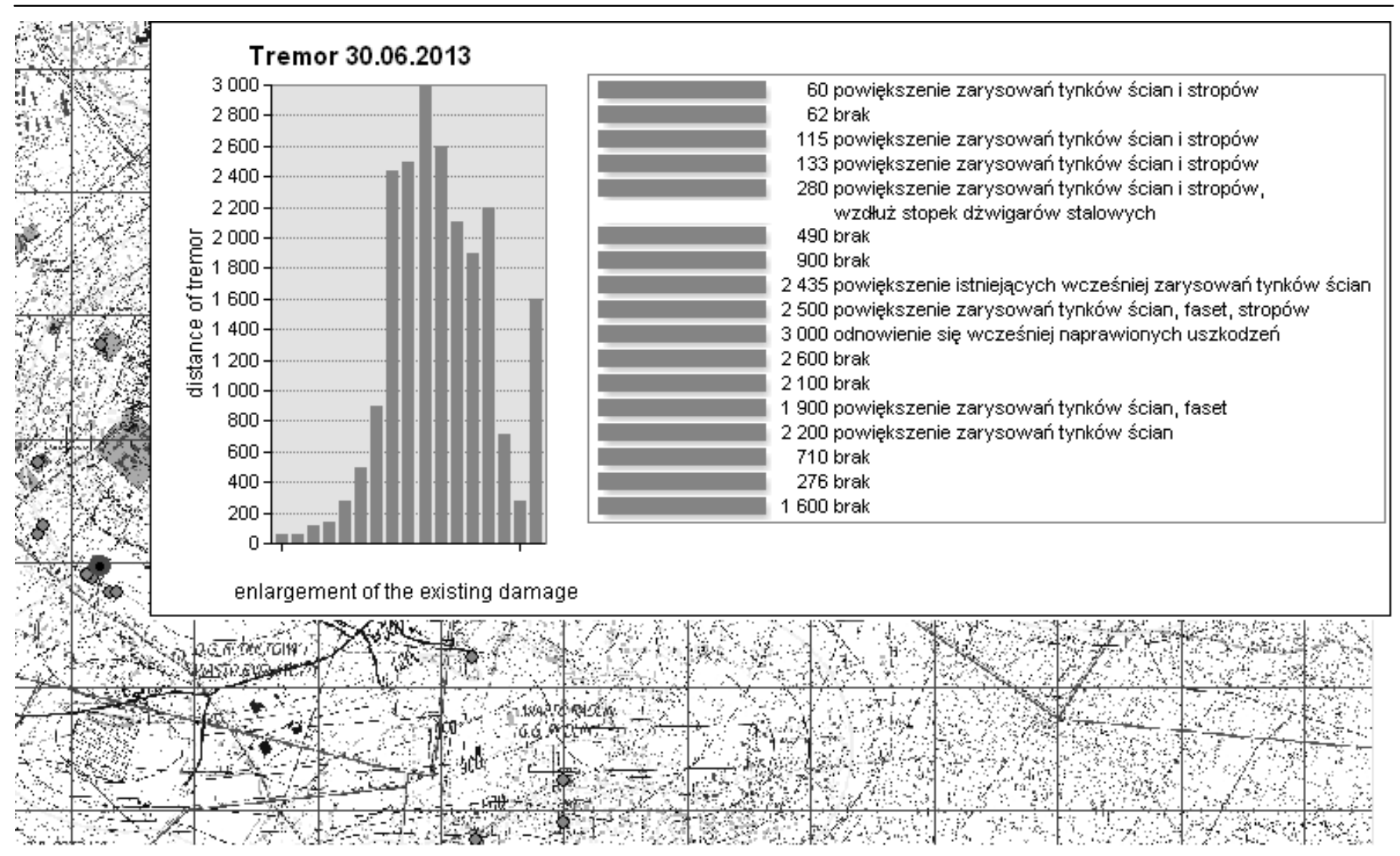

Fig. 11 The classification of objects as athe results of the damage depending on the distance from the epicentre

Enriched database on the structure of buildings can support the assessment on the dynamic resistance of the building objects. The assessment of the casual amount of damage with a tremor that occurred in the area of the buildings location. Additionally, it is possible to perform a series of analyzes, among other things, in the scope of the correlation of the velocityof the ground vibration and their duration with the observed damage ro the objects.

\section{SUMMARY}

In this article are presented the possibilities of the use of the ArcGIS system to support the assessment of the impact of the mining tremors on the building objects located on the surface area. This issue was presented on the example of the database elaborated for the building objects situated on the KWK "Rydultowy-Anna" area, that were damaged as a result of the mining tremors of a seismic energy of $10^{7} \mathrm{~J}$ caused by the exploitation conducted in years 20112013 in the seam 713/1-2.

The database was compiled in the ArcGIS system v. 10.1. It comprises 248 objects, including 240 building objects damaged as a result of the above-mentioned tremors and the 8 mining tremors. Spatial and descriptive attributes of the objects were specified on the basis on the analysis of the observed data that were obtained from the TMG department of the coal mine taking into account the tasks' realization in the scope of the assessment of the tremors impact on the building objects.

This article presents the procedure of this database elaboration, which can be applied in the mining industry. The possibilities of the use of the database to evaluate the influences were presented in the relation to the spatial analysis of the functions that are possible to be used in the ArcGIS system. Among others, the possibility of the support of the diagnostics of the the building objects that were damaged as a result of the tremors, the evaluation of the dynamic resistance of the objects and the evaluation of the connection of the causal nexus of the size of the damage with the tremor and the corelation, for example, of the velocity of the ground and the time of their duration with the observed damage to the buildings were pointed out.

\section{REFERENCES}

[1] Kompania Węglowa S.A. Oddział KWK „RydułtowyAnna", Dodatek nr 6 do Projektu Zagospodarowania Złoża KWK „Rydułtowy-Anna”, Rybnik: Kompania Węglowa S.A., 2014.

[2] Kompania Węglowa S.A. Oddział KWK „RyduttowyAnna", Plan Ruchu Zakładu Górniczego KWK „Rydułtowy-Anna”, 2013.

[3] Kompania Węglowa S.A. Oddział KWK „RydułtowyAnna”, Vademecum KWK „Rydułtowy-Anna”, Rydułtowy: Kompania Węglowa S.A., 2015.

[4] A. Krawczyk. "Geomatyka górnicza jako wyraz zastosowania środków formalnych geomatyki w geodezji górniczej", in Roczniki Geomatyki, tom 2, z. 2, 2004, pp. 172-180.

[5] J. Kabiesz et al, Raport roczny o stanie podstawowych zagrożeń naturalnych i technicznych w górnictwie węgla kamiennego, Katowice: Główny Instytut Górnictwa, 2015.

[6] Rozporzqdzenie Ministra Środowiska z dnia 22 grudnia 2011 r. w sprawie dokumentacji mierniczogeologicznej, Dz. U. 291, poz. 1713, 2011.

[7] Rozporzqdzenie Ministra Środowiska z dnia 28 października 2015 r. w sprawie dokumentacji mierniczogeologicznej, Dz. U. 2015, poz. 1941, 2015. 
[8] V. Sokoła-Szewioła and M. Poniewiera, „GIS systems in Polish coal mining." in Innovative technologies in mining and transport edited by A. W. Korczak, Katowice Moscow: 2014, pp. 71-105.
[9] J. Urbański. Zrozumieć GIS Analiza informacji przestrzennej, Warszawa: Wydawnictwo Naukowe PWN, 1997.

[10] Esri Polska, (2016, January), Geologia, [Online]. Available: http://www.esri.pl/branze/srodowisko/geologia/

dr hab. inż. Violetta Sokoła-Szewioła, prof. Pol. Śl, mgr inż. Monika Żogała

Silesian University of Technology, Faculty of Mining and Geology

ul. Akademicka 2A, 44-100 Gliwice, POLAND

e-mail: violetta.sokola-szewiola@polsl.pl

monika.zogala@polsl.pl 